\title{
Glossary of Principal Portuguese Terms
}

Devassa-a special judicial investigation

Estado da India - State of India, the name applied to the Portuguese possessions east of the Cape of Good Hope, of which Mozambique formed a part until $\mathrm{r} 75^{2}$

Funta do Comércio - Board of Trade

Machila - a rough, durable cotton cloth woven by the people of Zambesia

Patamar, patamares-an African or mulatto trading agent, usually a slave, who travelled in the interior on behalf of his master at the coast

Prazo-Portuguese Crown Estate, a major Afro-Portuguese political institution in Zambesia and the Kerimba Islands, the title-holder of which is usually known as a prazero

Residéncia-a judicial investigation conducted at the completion of an official's tenure of office to see if he had fulfilled, or contravened, his instruction

Santa Casa da Misericórdia-Holy House of Mercy, a charitable brotherhood

Senado da Câmara-Municipal Council

Velório-glass trade beads, usually Venetian

Weights

Arrátel $-0.459 \mathrm{~kg}$

Arroba: 32 arráteis-1 $4.688 \mathrm{~kg}$ Bar: 20 faraçolas- $247 \cdot 860 \mathrm{~kg}$

Bar: 4 quintais-234.900 kg

Faraçola: 27 arráteis-12.393 kg
Maina: $\frac{1}{12}$ faraşola- $-\mathrm{I} \cdot 03275 \mathrm{~kg}$

Onģa: $\frac{1}{16}$ arrátel $-0.0287 \mathrm{~kg}$ Quintal: 4 arrobas- $58 \cdot 725 \mathrm{~kg}$ Rubo: $\frac{1}{4}$ main $a-0 \cdot 25^{8} 19 \mathrm{~kg}$

\section{Currencies}

Cruzado - a silver coin equal to 400 reiis

Dollar-either the Spanish or Austrian Maria Theresa dollar, both of which were basic trading currencies in the Western Indian Ocean region.

Pataca-the Portuguese name for a dollar, equal in the eighteenth century first to three, then to four, and finally, when marked at Mozambique, to six cruzados

Piastre - the French name for dollar Real-the basic Portuguese monetary unit xiv 